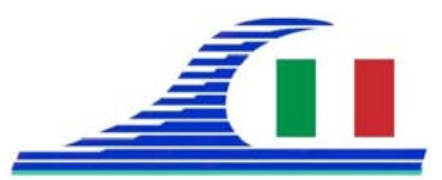

Conférence Méditerranéenne Côtière et Maritime EDITION 3, FERRARA, ITALIA (2015)

Coastal and Maritime Mediterranean Conference

Disponible en ligne - http://www.paralia.fr - Available online

\title{
Impacts of Storm Dirk on a gravel replenished shore: Preliminary results from Nice beach, French Riviera
}

\section{Olivier COHEN ${ }^{1}$, Rémi DUMASDELAGE ${ }^{2}$, Edward J. ANTHONY ${ }^{3}$}

1. Université de la Nouvelle-Calédonie, Centre des Nouvelles Études sur le Pacifique (EA 4242), 145 avenue James Cook, BP R4, 98851 Nouméa, Nouvelle Calédonie. olivier.cohen@univ-nc.nc

2. Mairie de Nice, Direction Eau, Air et Qualité des milieux, 59, rue Beaumont - 06364 Nice cedex 4, France.

remi.dumasdelage@ville-nice.fr

3. Université d'Aix-Marseille, CEREGE (UM 34), Technopôle de l'Arbois-

Méditerranée, BP80, 13545 Aix en Provence cedex 4, France.

anthony@cerege.fr

\begin{abstract}
:
Since 1976, the municipality of Nice has been monitoring the "Promenade des Anglais" beach through a total of 50 measurement transects. Comparison of two high precision GNSS surveys carried out at the end of November and December 2013 enable detection of the impacts of the $25^{\text {th }}$ December Storm Dirk on the beach. Modelling of the hydrodynamics at high spatial resolution provides further useful information on storm impacts.
\end{abstract}

Keywords: Nice, French Riviera, Gravel beach, Storm, Beach profiling, Hydrodynamic modelling, Beach replenishment, Erosion, Beach management.

\section{Introduction}

Nice is located in the southeast of France on the French Riviera in the Maritime Alps department. A gravel beach fronting the city extends $4.5 \mathrm{~km}$ along the northeastern part of the "Baie des Anges". The hinterland is high, steep and is directly linked to the sea with an extremely narrow continental shelf (figure 1). The tidal range is low (50 cm at spring tide). The most frequent waves come from SW to SE (65\%). Offshore, they are usually of low energy: from 2002 to 2014, 75\% of significant heights (Hs) were inferior or equal to $0.7 \mathrm{~m}$ and $99 \%$ inferior or equal to $1.9 \mathrm{~m}$. However, storms can occur during which waves are only slightly dampened by the steep shoreface and break on the beach.

This beach is highly managed and natural sediment inputs are extremely limited (COHEN \& ANTHONY, 2007). In order to solve coastal erosion and maintain the beach, the municipal authorities initiated a nourishment scheme in 1976. The beach width evolution was also monitored using a network of 50 transects with an average of 3 measurements per year. A statistical cross-analysis of beach width and replenishment 
Côtes méditerranéennes menacées :

Risques et défis dans le contexte du changement climatique

data shows that from 1976 to 2000, massive nourishment $\left(525910 \mathrm{~m}^{3}\right)$ resulted in mild enlargement and then stabilization of the beach mean width - around $28 \mathrm{~m}$ (COHEN, 2014). After 2000, the reduction of gravel nourishment led to overall erosion (mean width=26 $\mathrm{m}$ in 2012). In more detail, the stable or accreting parts of the beach during the first period (1976-2000) evolved into ones of lower accretion or erosion. Where erosion existed, it became more severe. Therefore, the massive nourishment gravel volume (582900 $\mathrm{m}^{3}$ from 1976 to 2013) emplaced on the beach seems to have been evacuated offshore towards the very steep shoreface and probably even further downslope. In an earlier paper (ANTHONY et al., 2011), we pointed out the insufficiencies of the beach-width measurement strategy: beach width is not exactly proportional to beach volume; the natural evolution of the beach shape; and the impact of artificial beach reprofiling every Spring to enlarge beach width cannot be precisely evaluated. We hypothesized that this reprofiling, especially the lowering of the profile and spreading down of pebbles using machinery, caused sediment loss offshore.

In this note, we present new data focusing on the short timescale relationship between the evolution of the profile in the central and northeastern sectors of the beach and highenergy hydrodynamic conditions associated with Storm Dirk that struck on $25^{\text {th }}$ December 2013.
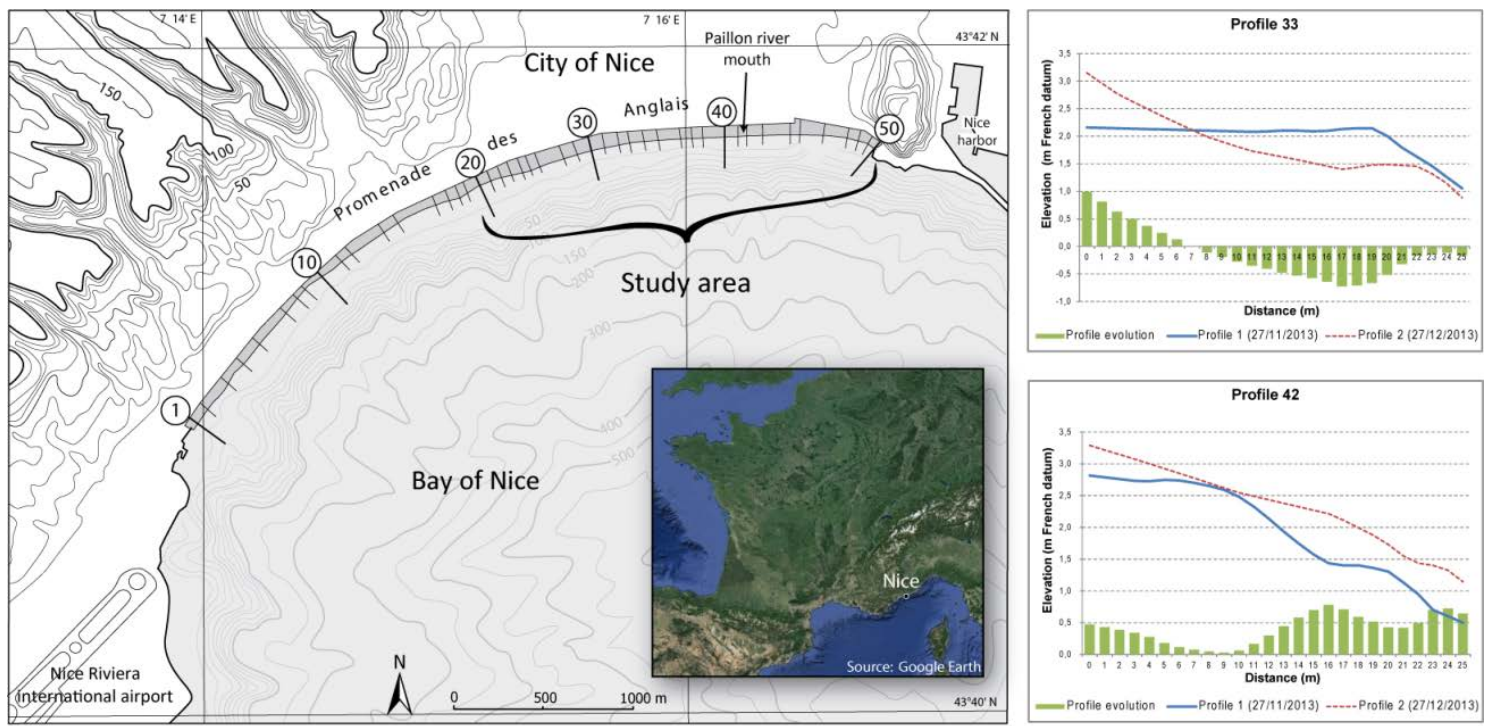

Figure 1. Location of the study site and monitoring transects; two examples of beach profile evolution.

\section{Materials and methods}

Since November 2013, the beach has been surveyed using a high precision differential Global Navigation Satellite System (GNSS). The data collected helps to monitor not only the beach width evolution and the sediment budget, but also the profile 
morphodynamics. The first GNSS measurements were carried out on November $27^{\text {th }}$, the second on December $27^{\text {th }}$, two days after Storm Dirk.

In order to have a good grasp of the hydrodynamics during the storm, numerical modelling based on TELEMAC was used. TELEMAC is a free and open-source system developed by EDF's R\&D “Laboratoire National d'Hydraulique et Environnement" (LNHE) and a consortium of several firms including HR-Wallingford. The two modules of this integrated tool, TOMAWAC (TELEMAC-based Operational Model Addressing Wave Action Computation) and TELEMAC2D, were used to take into account the impact of waves and currents on the beach. The sea state model TOMAWAC solves the balance equation of the action density directional spectrum on a spatial computational grid (GODA, 2000; KOMEN et al., 1994; DUMASDELAGE et al., 2013). Moreover by coupling TOMAWAC with the hydrodynamic model TELEMAC2D, we obtained results on water depths and current velocities induced by wave radiation stress. The shallow water/Saint-Venant equations are solved by TELEMAC2D in two space horizontal dimensions (HERVOUET, 2007; DUMASDELAGE et al., 2014). The two modules use high-capacity algorithms based on finite elements. Thus, the spatial discretization of the study area was carried out with an unstructured mesh of triangle elements. Three zones of different mesh sizes were configured on the computational grid. Since much of the interaction between waves, currents and the seabed occur near the shore, we refined the mesh density with a resolution of $3 \mathrm{~m}$ close to the coastline. The mesh resolution gradually increases from the shore to the $-250 \mathrm{~m}$ isobath. The grid used for the computation contains a total of 150,000 nodes. On the boundary of this area a wave spectrum was set up based on Storm Dirk data: direction $=185^{\circ}, H s=2.7 \mathrm{~m}$ (significant wave height) and $T p=8.5 \mathrm{~s}$ (peak period).

\section{First results}

The comparison of the measurements before and after the storm shows overall erosion of all except five of the beach profiles (figure 2a). On all the profiles, minor accretion on the upper beach and more important erosion on the lower beach are observed; the mid-beach platform due to reprofiling disappears; a berm is created on the lower beach; the slope increases (example of profile 33 in figure 1). These changes are typical of gravel beaches: the profile becomes more reflexive to adapt to stormy conditions. However, in five cases, mainly profiles 42 and 43, accretion is detected (example of profile 42 in figure 1 ).

Figure $2 \mathrm{~b}$ shows the significant wave height $(\mathrm{Hs})$ and longshore current velocities $(\mathrm{V})$ on the inner shoreface. Hs increases progressively from profile 20 to 40 as dissipation on the shoreface decreases. Similarly, $V$ increases with changes in shoreline orientation. But eastward, after profile 40, $H s$ and $V$ values suddenly decline. Then, they tend to increase once again until the end of the beach. Local variability may be due to fine-scale 
Côtes méditerranéennes menacées :

Risques et défis dans le contexte du changement climatique

changes in bathymetry. The model indicates a global longshore current towards the northeast.

The Bravais-Pearson correlation coefficient computed on the whole study zone using profile volume changes and $H s$ is moderate $\left(r_{20-50}=0.57\right)$, but it increases on either side of the Paillon river mouth $\left(r_{20-41}=0.74 ; r_{42-50}=0.6\right)$. The global correlation between profile volume changes and $V$ is weak $\left(\mathrm{r}_{20-50}=0.3\right)$, weaker on the west side of the river mouth $\left(\mathrm{r}_{20-41}=0.03\right)$ and moderate on the east side $\left(\mathrm{r}_{42-50}=0.5\right)$.

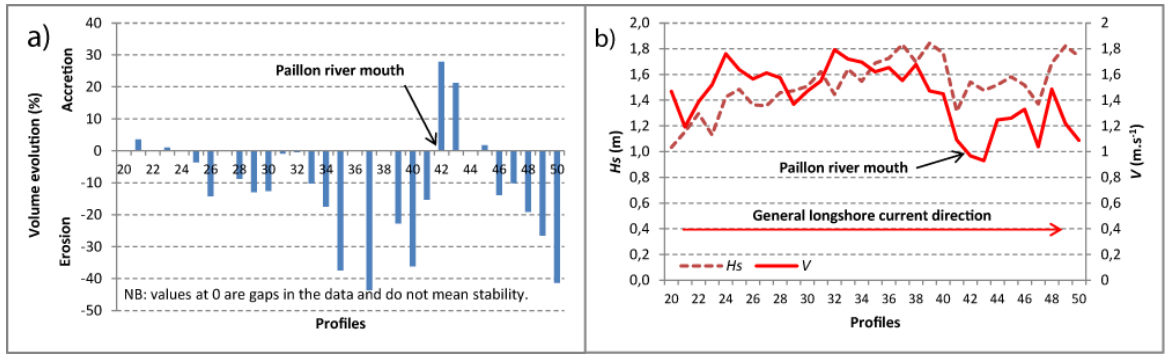

Figure 2. (a)evolution of beach profiles,(b) alongshore evolution of Hs and V.

\section{Discussion and conclusion}

Explaining the accretion of profiles 42 and 43 is quite difficult with the data at our disposal. This situation could be related to wave diffraction caused by the groyne located on the east bank of the river mouth. We also wonder whether in the lower energy zone in front of these two profiles, the longshore current could be inverted.

The first statistical results show that beach evolution could be related more to wave height than to longshore current velocity. These preliminary results are promising but we are aware that further work still needs to be carried out. First, we need to work with a complete topographical set of data (there were gaps in these preliminary ones). We have to take into account the changes in wave direction during the storm. We also have to model the weather conditions before the storm (from November $27^{\text {th }}$ to December $\left.24^{\text {th }}\right)$.

The topographical changes are, however, very interesting. They plead in favour of our initial hypothesis: spreading down of pebbles to increase beach width does cause sediment loss offshore. Therefore the policy of annual reprofiling of the beach may need to be called into question.

\section{References}

ANTHONY E.J., COHEN O., SABATIER F. (2011). Chronic offshore loss of nourishment on Nice beach, French Riviera: a case of over-nourishment of a steep beach? Coastal Engineering, Vol.. 58, pp 374-383. http://dx.doi.org/10.1016/j.coastaleng.2010.11.001 
Mediterranean coasts at threat: Hazards and challenges in the context of climate variability

COHEN O. (2014). 38 ans de rechargements sur la plage de Nice, Côte d'Azur : une synthèse statistique. XIII ${ }^{\text {èmes }}$ Journées Nationales Génie Côtier - Génie Civil, Dunkerque, pp 281-288. http://dx.doi.org/10.5150/jngcgc.2014.031

COHEN O., ANTHONY E.J. (2007). Gravel beach erosion and nourishment in Nice, French Riviera. Méditerranée, Vol. 108, pp 98-103. http://dx.doi.org/10.4000/mediterranee.182

DUMASDELAGE R., DELESTRE O., CLAMOND D., BONNIN A., CERUTI P., MORETTI M., GOURBESVILLE P. (2013). Modeling of the erosion phenomena on Nice shoreface and the impact of coastal structures. Proc. $35^{\text {th }}$ IAHR World Congress, Chengdu, $7 \mathrm{p}$.

DUMASDELAGE R., DELESTRE O., CLAMOND D., BONNIN A., MORETTI M., CERUTI P., GOURBESVILLE P. (2014). Numerical modeling of the erosion phenomena on Nice shoreface using TELEMAC system. Proc. $3^{\text {rd }}$ IAHR Europe Congress, Porto, $9 \mathrm{p}$.

GODA Y. (2000). Random Seas and Design of Maritime Structures. Advanced Series on Ocean Engineering 15 ( $2^{\text {nd }}$ ed.), Singapore, World Scientific, 443 p. http://dx.doi.org/10.1142/3587

HERVOUET J-M. (2007). Hydrodynamics of free surface flows modeling with the finite element method. Wiley, 341 p. http://dx.doi.org/10.1002/9780470319628

KOMEN G.J., CAVALERI L., DONELAN M., HASSELMANN K., HASSELMANN S., JANSEN P.A.E.M. (199. Dynamics and Modelling of ocean waves. Cambridge University Press, 532 p. http://dx.doi.org/10.1017/CBO9780511628955 
Côtes méditerranéennes menacées :

Risques et défis dans le contexte du changement climatique 